\title{
Review of 'Searching for Boko Haram. A History of Violence in Central Africa' by Scott MacEachern
}

\section{Tatyana S. Denisova}

Institute for African Studies, Moscow

\section{Sergey V. Kostelyanets}

Institute for African Studies, Peoples'

Friendship University of Russia, National Research

University Higher School of Economics, Moscow

Review of Scott MacEachern, Searching for Boko Haram. A History of Violence in Central Africa. New York: Oxford University Press, 2018. 233 pp. ISBN 9780190492526. In English.

Scott MacEachern's book Searching for Boko Haram. A History of Violence in Central Africa delves deep into the historical origins of the militant Islamist group Boko Haram, which emerged in the north of Nigeria in the mid-1990s. The group stepped up its activities in the early 2000s, and until the mid-2010s carried out a number of largeand many small-scale terrorist attacks that claimed up to 20,000 lives. In 2015, a coalition of the armed forces of Benin, Cameroon, Chad, Niger and Nigeria was formed to counter Boko Haram. Consequently, Boko Haram units were driven out to the northeast of Nigeria and further beyond its borders. However, they have found a haven in border regions of Nigeria, Cameroon and $\mathrm{Chad}$, which for that reason came into the focus of the author's attention. From these hideouts Boko Haram continues its campaign of terror, which has recently become very closely interrelated with organized crime.

The book is very unusual for a number of reasons. First of all, it was written by a Canadian archaeologist, who for many years (from

Social Evolution \& History, Vol. 17, No. 1, March 2018 202-208 
1984 until present) has been leading excavations in northern Nigeria and northern Cameroon - that is, in the territories that belong to the Lake Chad Basin and are now controlled by the Boko Haram militants. At the same time, the whole book is permeated with the author's love for this part of Africa and sympathy for the people who live there and often have to engage in illegal activities simply for the sake of survival. MacEachern's genuine understanding of the socio-political and economic reasons for the formation of Boko Haram is due to his profound knowledge of the region's history. Boko Haram is a religious movement that has transformed into a terrorist group that, with the loss of its original goals of the 'purification' of Islam, the introduction of Sharia law throughout the country, and opposition to the central government of Nigeria, which had been dominated by Christian southerners until Muslim northerner Muhammadu Buhari came into the office in 2015 , and as a result of forced displacement to the border areas, is increasingly turning into a criminal organization. At present, terrorist attacks are becoming less frequent, as militants are mainly engaged in looting, smuggling, kidnapping people for ransom or into slavery, etc.

Unlike other authors who wrote on Boko Haram and who mainly saw the origins of the group in the Maitatsine Muslim sect in northern Nigeria in the 1980s, thus limiting the scope of their research to a 20-year historical period, MacEachern, relying on his own archaeological research, demonstrates the dynamics of the development of the people living in the Lake Chad Basin for two and a half millennia. Today, the region is inhabited by a variety of ethnic groups speaking different languages and having different histories. The largest of these are Kanuri, Hausa, Fulani, Shuwa Arab, Kotoko, and Kanembu. Since time immemorial, the main source of enrichment for the leaders of these and numerous smaller tribes was the abduction of people, especially young women, with the aim of turning them into slaves. The author draws a clear parallel with the kidnapping of almost 300 schoolgirls by Boko Haram militants in the Nigerian city of Chibok in 2014. Some of the girls became wives and concubines of militants, some were sold into slavery outside the country, and some voluntarily or forcefully joined the ranks of combatants. As MacEachern persuasively argues, even vindicating the militants to some degree, when performing the attack they 'were peering through a window into the deep past of African slave-raiding' (p. 16).

The book puts a special emphasis on the cultural logics within which violence takes place and asks why violence makes sense to certain people at certain times, and whether there are historical continui- 
ties in the way violence is used toward individual and communal goals in particular circumstances. MacEachern examines the deep history of Boko Haram, and in particular the origins of different cultural groups that have been swept up in the conflict.

The special value of the book lies in the fact that the author considers the background and history of the formation and activities of Boko Haram from different points of view - religious, military, political, cultural and socio-economic. He points to underdevelopment, wide-scale corruption and exploitation of common people that have marked the colonial and postcolonial Nigerian state and its neighbors in the region. Indeed, Boko Haram is a movement made up of people, perhaps especially young men but also women, who see little hope in this world and the redemption of violence as their only means of making their way to the next (p. 18).

Much attention, and rightly so, MacEachern pays to the phenomenon of frontiers and borderlands. As early as in ancient times, the border areas, which were outside the control of the states of KanemBorno, Baghirmi, Wandala, etc., became a refuge for escaped criminals and dissidents. The author considers the roles of states along their frontiers, particularly with the deep involvement of the state in the expansion and sustainment of large-scale slave trades. Slave-raiding and trading were potential sources of wealth, both for state elites in capitals and for ruthless and determined people living on state borders (p. 124). In this sense, contemporary Boko Haram may be considered a 'worthy' successor to the frontier bandits of former times. However, MacEachern, recalling that in the pre-colonial and colonial times cross-border trade in slaves, livestock, salt, sugar and other goods was a normal and rather legitimate business, and that in the Lake Chad area (as in other regions of Africa) centuries-old trade routes still remain operational, notes that even today the population of border areas and local authorities do not consider this 'kind of human activity' illegal. However, there has now emerged a new problem for border communities, which is a very different form of wealth accumulation 'lawless' activities carried out by local criminal gangs, Boko Haram militants, as well as regular army soldiers and policemen, who sometimes do not even bother to change their uniforms to civilian clothes. As these actors of violence may compete or cooperate at different times, it is not always possible to distinguish an Islamist militant from an ordinary robber.

Moving on to the activities of Boko Haram in 2017, the author points out that the group continues to attack communities in the south- 
ern areas of the Lake Chad Basin, although the nature of terror and military confrontation has changed markedly since the mid-2000s. The armed attacks on police stations and military posts have been replaced by the laying of mines on roads and attacks carried out by suicide bombers - often girls and young women - in village markets. The incessant disruptions of the daily routine have led the peasants to cease planting and harvesting, and hunger has become commonplace. Naturally, under the circumstances, the author fears that his attempts to view the violence carried out by Boko Haram in the historical or cultural context may seem unjustified to some readers: as an excuse for Islamist attacks. Yet, he refutes this position for a number of reasons.

First, he proves that the past, present and future of the region are closely interrelated and that even the most brutal actions of Boko Haram can at least partially be explained by events that had occurred in the past, when misunderstandings had arisen between individual ethnic and confessional groups, the periphery and the center, which today have become so acute that have transformed into violence. Terrorists in this region, as well as all over the world, do not engender accidental violence: on the contrary, it is connected with what had happened in the region earlier, and militants, if not always their victims, comprehend violence in this context. Second, the study of the earlier context in which violence had been committed in the region makes it possible to explain why the population is helpless against it and to find possible ways to combat modern terrorism. Third, the study of modern processes related to Boko Haram can help other historians better understand past events (p. 157).

The author also touches upon the ethnic aspect of the group's activities. Recounting how Boko Haram emerged, he notes that the initial followers of the organization's first leader Mohammed Yusuf were young members of the Kanuri ethnic group. Boko Haram's current leader Abubakar Shekau is also a Kanuri. Khalid al-Barnawi, the leader of the splinter group Ansaru, who is currently in prison in Nigeria, is a Kanuri as well, just like many other field commanders in both groups. Most of the rank-and-file fighters are recruited from the Kanuri; moreover, Boko Haram has carried out numerous attacks on nonKanuri populations around the region, which have caused a great deal of destruction and damage, which is directly related to the longstanding feud between the Kanem-Borno Empire and Sokoto Caliphate, inhabited mainly by Hausa and Fulani. Many non-Kanuri ethnic groups in the region were historically targeted by slave raids, and MacEachern appropriately places those Boko Haram attacks in a his- 
torical sequence that extends back more or less continuously to the Kanuri slave raiding expeditions of five centuries ago. In another instance, amid fighting near Lake Chad in mid-2015, Boko Haram militants sought out and killed Shuwa Arab civilians while sparing their Kanuri neighbors, apparently in reprisal for attacks on the militants and on local communities by predominantly Shuwa Chadian Army units (p. 160).

However, the author himself suggests that the scheme Boko Haram employs for recruiting new members may evolve. The group needed fighters, and most of Nigeria's northerners were dissatisfied with the central government's policies: indeed, besides the religious prerequisites for the rise of Islamism (e.g., the refusal of Muslim fanatics to recognize the secular nature of the Nigerian state), the reasons for religious unrest included the aggravation of social inequality in the country in general and in the northern states in particular; rising unemployment among educated and uneducated youth; lack of access to secular education; unfair distribution of oil revenues between the states; economic and political marginalization of the northern regions. That is why the fundamentalists claimed that the federal government was unworthy of the loyalty of the orthodox Muslims, called for attacks on police stations and other state institutions and encouraged their supporters to quit secular schools and the civil service. As a result, Boko Haram has managed to incorporate many non-Kanuri fighters into its ranks. Yet the Boko Haram movement, just like Maitatsine before it, lacks a clear program and ideology; the leaders of these organizations only called for a struggle for the 'purity of Islam', thus protesting against the existing order of things. Interestingly, Boko Haram compares itself with the 1804-1808 jihadist movement of Usman dan Fodio and views itself as a modern remedy against the corrupt and sinful state apparatus.

In recent years the process of transformation of the religious movement into a criminal structure has become irreversible. As the author notes, Boko Haram has made good use of the potentials of the border areas in carrying out their operations. In the military sense, the Mandara Mountains and the plains between the mountains provide the militants with a safe haven, a good view of the terrain and a convenient tactical position: the rocky hillsides and crests of the massif offer extraordinarily strong defensive positions.

In addition, the areas bordering Cameroon, on which MacEachern specially focuses, are interlaced with trails and pathways that have been used for smuggling and banditry for centuries. The author raises 
the valid question: what could such illegal economic activities have to do with the actions of a modern terrorist organization like Boko Haram, which presumably pursues very different objectives? He answers the question himself: in fact, the day-to-day activities of Boko Haram on the Cameroon-Nigeria frontier have a great deal in common with the activities of smugglers and bandits during the last few decades, in part because there seems to be a lot of overlap between these two groups (p. 167).

The regime of violence and enrichment that has been established in this territory by Boko Haram since mid-2010 does not differ too much from what existed in the region in previous centuries, although the focus of wealth accumulation has shifted from kidnapping people and selling them into slavery to smuggling gasoline and other goods. There is an indubitable link between the cross-border trade of the previous centuries, the illegal smuggling of goods, which has become the daily activity of frontier communities lacking other means of subsistence, and the activities of Boko Haram. This continuity is due to the fact that smugglers, highwaymen and terrorist rebels belong to the same social, ethnic and religious groups related by friendship or kinship; they work closely together and use the same weapons, mobile phones and vehicles - motorcycles and small trucks. When Boko Haram fighters kidnap foreigners for ransom, it reminds of the actions of ordinary bandits that were commonplace in these territories in the 1990s. Another similarity is the links that exist between Boko Haram and border criminal groups and local - or often national - political and business elites which are either directly involved in smuggling or facilitate it indirectly.

Boko Haram's criminal activities are closely linked to the challenges that young people usually face in this part of Africa if they lack the means or political connections necessary to move up the ladder of the social hierarchy. In order not to remain, according to the apt expression of the author, 'in a status of perpetual adolescence' (p. 198), they either join the ranks of militant groups or criminal structures.

The governments of the countries of the region are constantly predicting the defeat of Boko Haram, but so far there is no evidence of this. At some point, the movement will finally be eliminated, but most likely because regional elites will no longer use this name. The author opines that it is most likely that Boko Haram rebels will gradually fade into the condition of increased banditry, frontier lawlessness, and insurgency, as was the case in the region after the Chadian wars of the 1980 s and early 1990s (p. 205). There are a lot of young people who 
grew up with a gun in their hands and do not know what else to do. They will be reluctant to refuse wealth and power attainable through the use of weapons. In any case, they will prefer the career of a rebel or smuggler to the half-starved existence of a peasant.

Scott MacEachern's monograph makes a notable contribution to the study of the history of the Lake Chad Basin region in general and to the study of the activities of the militant Boko Haram group in particular. Indeed, the book may take a rightful place among the works of modern historians and social anthropologists. 